Vol. 23, No. 2, September 2020, hlm. 84-93

p-ISSN: 1410-9344; e-ISSN: 2549-5631

homepage: http://journals.ums.ac.id/index.php/warta

\title{
Terapi Berhenti Merokok dengan Spiritual Emotional Freedom Technique (SEFT)
}

\author{
Eny Purwandari, Elvandari Pubianti, Mita Sofiana M, Muhammad Didik Nugroho, Freddy \\ Program Studi Magister Psikologi \\ Universitas Muhammadiyah Surakarta \\ Email : eny.purwandari@ums.ac.id
}

\begin{tabular}{l}
\hline \multicolumn{1}{c}{ Article Info } \\
\hline Submitted: 16 December 2019 \\
Revised: 15 January 2020 \\
Accepted: 7 March 2020 \\
Published: 7 April 2020
\end{tabular}

Keywords : adolescent, SEFT, smoke, therapy

\begin{abstract}
Teenagers as the next generation of the nation need to be prepared to become healthy and quality human beings. However, our young generation is being threatened because of cigarettes. Based on a study conducted by the School of Strategic and Global Studies for the University of Indonesia's national guarantee study in 2018 found that active smokers were aged 25-38 with a percentage of 44.75 percent. Young people have a significant percentage of 33.03 percent of the 1000 respondents aged 18-24 years who are still active smokers. This condition was found by Al-Kautsar High School as a partner. Based on information obtained from the Al-Kautsar High School BK teacher, it was found that most male students smoke. This is of concern to the service team to carry out community service programs at Al-Kautsar High School with the theme "SELF DEVELOPMENT TRAINING FOR TEENAGERS". This service activity aims to be able to provide education to high school teens about the dangers of smoking in terms of health, emotional and spiritual. Besides this activity is also to apply smoking cessation interventions to students as active smokers in groups and help students overcome smoking addiction. The method used with psychodeducation and SEFT therapy. SEFT therapy was carried out on 3 active smokers (as volunteers). SEFT Therapy, or an extension of the Spiritual Emotional Freedom Technique (SEFT) is one alternative therapy technique to overcome emotional and physical problems. Therapy is done by mild full-blooded nerve at certain points or meridians in the body. A series of systematic techniques are used in body systems to improve the state of mind, emotions, and behavior to reduce smoking. The results of SEFT therapy in this community service activity showed a decrease in the enjoyment scale felt by the child as indicated by nausea, dizziness, bitter, coughing and even vomiting. Giving this SEFT therapy can change the mindset of students to reduce their activity in smoking. So with SEFT therapy this is an alternative therapy that can be used for smoking addiction that can be applied.
\end{abstract}


Kata kunci: remaja, rokok, SEFT, terapi.

\begin{abstract}
Abstrak
Remaja sebagai generasi penerus bangsa perlu dipersiapkan menjadi manusia yang sehat dan berkualitas. Namun, generasi muda kita sedang terancam karena rokok. Berdasarkan studi yang dilakukan oleh School of Strategic and Global Studies untuk studi jaminan nasional Universitas Indonesia pada tahun 2018 menunjukkan perokok aktif adalah pada usia 25-38 tahun dengan persentase 44,75. Anak muda memiliki jumlah persentase yang cukup banyak yaitu sebanyak 33,03 persen pada 1000 responden berusia 18-24 tahun masih menjadi perokok aktif. Kondisi ini ditemukan SMA Al-Kautsar sebagai mitra. Berdasarkan informasi yang didapatkan dari guru BK SMA Al-Kautsar ditemukan sebagian besar siswa laki-laki merokok. Hal ini yang menjadi perhatian bagi tim pengabdian untuk melaksanakan program pengabdian masyarakat di SMA Al-Kautsar dengan tema "SELF DEVELOPMENT TRAINING FOR TEENAGERS". Kegiatan pengabdian ini bertujuan untuk dapat memberikan edukasi kepada remaja SMA akan bahaya merokok yang ditinjau dari sisi kesehatan, emosi dan spiritual. Selain itu kegiatan ini juga untuk mengaplikasikan intervensi berhenti merokok pada siswa sebagai perokok aktif secara berkelompok dan membantu siswa mengatasi kecanduan merokok. Metode yang digunakan dengan psikodedukasi dan terapi SEFT. Terapi SEFT dilakukan pada 3 perokok aktif (sebagai volunteer). SEFT Therapy, atau perpanjangan dari Spiritual Emotional Freedom Technique (SEFT) adalah salah satu teknik terapi alternatif untuk mengatasi masalah emosi dan fisik. Terapi dilakukan dengan cara totok ringan pada titik saraf tertentu atau meridian dalam tubuh. Serangkaian teknik yang sistematis digunakan dalam sistem tubuh untuk meningkatkan kondisi pikiran, emosi, dan perilaku untuk mengurangi kebiasaan merokok. Hasil dari terapi SEFT pada kegiatan pengabdian masyarakat ini menunjukkan adanya penurunan skala kenikmatan yang dirasakan anak yang ditunjukkan dengan adanya mual, pusing, pahit, batuk bahkan sampai muntah muntah. Pemberian terapi SEFT ini dapat mengubah mindset siswa untuk menurunkan aktivitasnya dalam merokok. Jadi, SEFT dapat menjadi alternatif terapi yang dapat digunakan untuk kecanduan merokok yang bisa diterapkan setting sekolah.
\end{abstract}

\section{PENDAHULUAN}

Sebuah laporan Southeast Asia Tobacco Control Alliance (SEATCA) pada tahun 2018 yang berjudul The Tobacco Control Atlas, Asean Region memaparkan bahwa Indonesia adalah negara dengan jumlah perokok terbanyak di Asean, yaitu 65,19 juta orang. Jumlah tersebut setara 34\% dari total penduduk Indonesia pada 2016. Dalam proses pembeliannya, sekitar 79.8\% perokok membelinya di kios, warung atau minimarket. Sedangkan $17.6 \%$ lainnya mendapatkan rokok dari supermarket. Terdapat 2,5 juta gerai yang menjadi pengecer rokok di
Indonesia. Jumlah ini belum memperhitungkan kios penjual rokok di pinggir-pinggir jalan (Lian \& Dorotheo, 2018).

Sementara jumlah perokok di Indonesia semakin meningkat, kecenderungan peningkatan prevalensi merokok terlihat lebih besar pada kelompok anak-anak dan remaja. Data Kementerian Kesehatan (Kemenkes) 2017 menyebut sebanyak 2-3 dari 10 anak Indonesia usia 15-19 tahun merupakan perokok aktif. Jumlah perokok usia anak (di bawah usia 18 tahun) juga meningkat dari 7,2\% pada 2013 menjadi $8,8 \%$ pada 2016. Fakta yang juga 
mengkhawatirkan, yaitu 34,71\% anak usia 5-17 tahun diketahui menghisap lebih dari 70 batang rokok perminggu (SUSENAS, 2016). Data ini dikuatkan oleh Studi yang dilakukan Sekolah Kajian Stratejik dan Global Pusat Kajian Jaminan Nasional Universitas Indonesia tahun 2018 terhadap 1.000 responden, baik perokok pasif maupun aktif yang mendapatkan hasil 33,03 persen pemuda usia 18-24 tahun masih menjadi perokok aktif, disusul oleh usia di atas 39 tahun sebanyak 41,75 persen. Sementara perokok paling aktif berada pada usia 25-38 tahun dengan persentase 44,75 persen.

Hal ini merupakan ancaman serius yang sedang dihadapi Indonesia karena prevalensi merokok juga membesar pada kelompok remaja. Masa remaja yang merupakan periode dimana individu memiliki keinginan yang kuat dalam mencari tahu dan berpetualang pada segala sesuatu yang belum pernah diketahuinya (Ali, 2010). Dengan rasa ingin tahu yang tinggi ini membuat remaja menjajal perilaku merokok tanpa memikirkan efek kedepannya. Hal ini juga menjadi keluhan Riskesdas pada tahun 2013 yang menunjukkan bahwa persentase usia merokok yang tinggi pada remaja dengan kelompok usia 15-19 tahun.

Masih tingginya angka perokok muda di Indonesia ini dinilai tak sesuai dengan Rencana Pembangunan Jangka Menengah Nasional (RPJMN) 2019 yang menargetkan penurunan prevalensi perokok menjadi 5,2 persen. Kondisi tersebut juga sangat menunjukkan betapa mengkhawatirkannya kualitas sumber daya manusia di Indonesia yang unggul di masa depan. Sebagaimana dengan hasil penelitian yang dilakukan oleh Farruq Yufarriqu pada tahun 2015 yang menemukan hasil bahwa rokok dapat menjadi faktor yang memengaruhi penurunan skor kualitas hidup perokok (Mufaza, 2015). Hal ini juga dikuatkan dengan Disertasi oleh Endah Saptutyningsih (2015) yang menyatakan adanya hubungan antara perilaku merokok dengan produktivitas kerja. Banyaknya penyakit yang diakibatkan oleh perilaku merokok aktif maupun pasif menjadi ancaman serius bagi program pembangunan sumber daya manusia Indonesia di masa depan.

Mengingat kondisi tersebut, maka diperlukan sebuah upaya preventif maupun kuratif untuk mencegah dan menyembuhkan remaja dari kecanduan merokok. Berdasarkan kondisi di atas, Mahasiswa Magister Psikologi Sains tahun angkatan 2017/2018 Universitas Muhammadiyah Surakarta mengadakan program pengabdian masyarakat yang mengambil tema "Self Development Training For Teenagers" yang dilaksanakan di SMA Al-Kautsar Program Khusus Kartasura, pada tanggal 13 Mei 2019. Salah satu diantara rangkaian materi yang diberikan dalam pengabdian masyarakat tersebut adalah materi "terapi SEFT sebagai terapi anti merokok".

Terapi Spiritual Emotional Freedom Technique (SEFT) merupakan perpaduan antara ilmu Akupuntur dan Psikologi yang disempurnakan dengan sentuhan spiritual yang bersifat universal. Teknik SEFT ini pertama kali digagas dan terus dikembangkan oleh seorang putra Indonesia sekaligus didaftarkan sebagai karya intelektual dan karya anak bangsa yaitu H.Ahmad Faiz Zainuddin, S.Psi., M.Sc. Terapi kecanduan dengan menggunakan metode SEFT adalah sebuah terapi yang menggabungkan energi psikologi, akupuntur dengan spiritualitas yang digabung menjadi 15 teknik terapi. SEFT sebagai metode baru dalam melakukan EFT (Emotional Freedom Technique) yang ditemukan oleh Ahmad Faiz Zainuddin, pertama kali melakukannya secara spontan, dan ternyata berhasil. Lalu mengulangnya beberapa kali dalam beberapa kasus dan berhasil dan mempraktekannya pada ratusan orang, ternyata hasilnya sangat bagus. Ketika orang-orang yang dibantu dan ditawari mengatasi masalahnya dengan EFT versi Gary Craig atau SEFT versi Ahmad Faiz kebanyakan mereka lebih suka SEFT (Zainuddin, 2006).

Berdasarkan penelitian yang dilakukan oleh Nurjanah (2019) menemukan hasil bahwa terapi SEFT pada kasus kecanduan merokok pada saat terapi berhasil membuat siswa yang kecanduan merokok berhenti merokoknya karena merasakan mual, pusing, pahit, batuk bahkan sampai muntah-muntah. Dengan menggunakan metode SEFT pula, tim Pengabdian Masyarakat Magister Psikologi UMS tahun ajaran 2017/2018 melakukan terapi SEFT kepada 3 orang siswa perokok aktif berdasarkan informasi yang didapatkan dari guru BK. Tujuan terapi SEFT dalam kegiatan ini adalah untuk memberikan 
edukasi kepada remaja SMA akan bahaya merokok bagi siswa ditinjau dari sisi kesehatan, emosi dan spiritual. Kegiatan ini juga untuk mengaplikasikan intervensi berhenti merokok kepada siswa sebagai perokok aktif secara berkelompok. Dengan dilaksanakan kegiatan pengabdian ini diharapkan dapat meningkatkan pengetahuan siswa dan siswi mengenai bahaya merokok yang dapat mengancam kesehatan fisik dan psikis, mengurangi atau menghilangkan kebiasaan merokok siswa dan siswi perokok aktif, menerapkan ilmu SEFT dalam kehidupan sehari-hari siswa dan siswi di SMA Al-Kautsar Sukoharjo.

\section{METODE PELAKSANAAN KEGIATAN}

Sebelum memberikan Terapi SEFT pada siswa sekolah, tim pengabdian memberikan psikoedukasi dengan menyampaikan materi terkait bahaya perilaku merokok bagi kesehatan fisik dan psikis. Selain menjadi sebuah awalan bagi siswa, materi ini juga menjadi pegangan bagi siswa dalam melaksanakan kegiatan. Kegiatan ini juga dapat memerkuat siswa untuk memasuki Tahapan SEFT yang dikemukakan oleh Ahmad Faiz (Zainuddin, 2006) yang memiliki tiga tahapan diantaranya adalah The Set-Up, The Tun-In, The Tapping.

Tim pengabdian melakukan proses pelaksanaan SEFT secara berkelompok melalui 3 tahapan yaitu The Set Up, The Tun-In, dan The Tapping. Berikut penjabaran proses pelaksanaan Tahapan SEFT yang tertera pada bagan 1 .

\section{Langkah Pertama}

Proses langkah awal yang dilakukan adalah The Set-Up. Tahapan ini merupakan langkah untuk menetralisir "Psychologycal Reversal" atau "Perlawanan Psikologis" (biasanya berupa pikiran negatif spontan atau keyakinan bawah sadar negatif). The Set-up bertujuan untuk memastikan agar aliran energi kita terarahkan dengan tepat. Contohnnya adalah "Saya tidak bisa lepas dari kecanduan merokok"

Dalam kegiatan Set Up yang akan dilakukan adalah sebagai berikut :

1. Pertama, terapis meminta siswa memulai dengan membaca Bismillahirrahmanirrahim. Karena untuk setiap melakukan kebaikan awali dengan Bismillah dan akhiri dengan Alhamdulillah.

2. Kedua, terapis memberikan kalimat SET-UP dan meminta siswa untuk mengikutinya dengan kalimat sebagai berikut "Ucapkanlah kalimat SET-UP berikut dengan khusyu, ikhlas dan pasrah sebanyak 3 kali, "Ya Allah... walaupun saya ingin merokok, saya ikhlas menerima masalah saya ini. Dan saya pasrahkan pada-Mu kesembuhan saya."

\section{Langkah Kedua}

Tahapan selanjutnya adalah The TuneIn, Tune-In merupakan keadaan untuk mengarahkan pikiran kita pada keluhan yang dirasakan. Untuk masalah fisik, kita melakukan

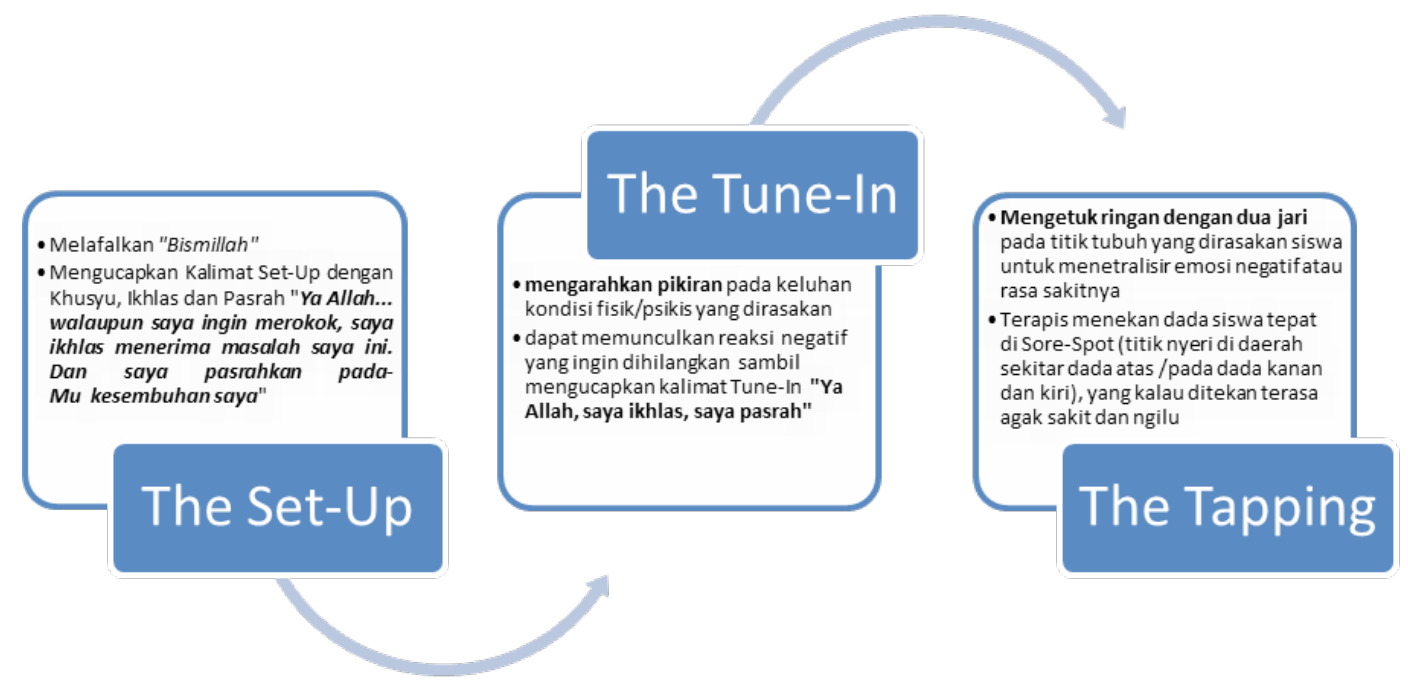

Bagan 1. Tahapan Terapi SEFT 
Tune-In ini dengan cara merasakan rasa sakit yang kita alami, lalu mengarahkan pikiran kita pada rasa sakit, dibarengi dengan hati dan mulut kita mengatakan kalimat Tune In.

Pada kegiatan ini siswa yang mendapatkan intervensi SEFT diminta untuk membayangkan kenikmatan saat merokok, Dengan diiringi kalimat Tune -In "Ya Allah saya ikhlas, saya pasrah" atau "Ya Allah saya ikhlas menerima sakit saya ini dan saya pasrahkan pada-Mu kesembuhan saya". Untuk masalah psikis atau emosi, kita melakukan Tune-In dengan cara memikirkan sesuatu atau peristiwa spesifik tertentu yang dapat membangkitkan emosi negatif yang ingin kita hilangkan. Ketika terjadi reaksi negatif (marah, sedih, takut, dsb) hati dan mulut kita mengatakan, "Ya Allah, saya ikhlas, saya pasrah." Bersamaan dengan Tune-In ini kita melakukan langkah ketiga (tapping). Pada proses inilah (tune-in yang dibarengi tapping) kita menetralisir energi negatif atau rasa sakit fisik.

\section{Langkah Ketiga}

Langkah Ketiga adalah Tapping. The Tapping adalah mengetuk ringan dengan dua ujung jari pada titik-titik tertentu di tubuh kita sambil terus tune-in. Titik-titik ini adalah kunci dari "the Major Energy Meridians", yang jika kita ketuk beberapa kali yang akan berdampak pada netralisirnya emosi negatif atau rasa sakit yang kita rasakan. Karena aliran energi tubuh berjalan dengan normal dan seimbang kembali. Kita harus khusyuk sambil terus berdzikir saya ikhlas, saya pasrah ya Allah, fokuskan hanya pada Allah, lupakan yang lain, konsentrasilah terus dalam dzikir.

Sambil mengucapkan kalimat The Tune-In , Terapis menekan dada klien tepat di Sore-Spot. Sore-spot adalah titik nyeri di daerah sekitar dada atas (pada dada kanan dan kiri), yang kalau ditekan terasa agak sakit dan ngilu. Karenanya terapis akan memulai menerapi tubuh bagian kanan terlebih dahulu.

Jumlah titik tapping ada 9 untuk versi singkat dan ditambah 9 lagi menjadi 18 untuk versi lengkap. Keras atau lembutnya ketukan disesuaikan dengan berat tidaknya permasalahan. Untuk kegiatan di atas, klien mendapatkan tapping untuk 9 titik sore spot yang diakhiri dengan menarik nafas panjang sambil mengucapkan syukur.

\section{HASIL DAN PEMBAHASAN}

Sebelum memasuki tahapan SEFT, tim pengabdian melakukan asessmen kepada peserta mengenai level kenikmatan saat merokok. Siswa diminta mengklarifikasi masalah dimana terapis meminta siswa untuk mengambil rokok dan mendekatkan kehidung. Kemudian siswa diminta untuk mencium atau membaui aroma rokok. Setelah itu siswa mengukur dan menentukan tingkat/skala Keinginan Merokok dengan range score antara 0-10, dimana $0=$ tidak ada keinginan merokok sama sekali, $10=$ tingkat keinginan maksimum/sangat ingin merokok. Sebagian besar peserta memberikan jawaban dalam kenikmatan merokok antara level 7-9 yang merupakan tergolong sedang. Proses assesmen ini dilakukan untuk mengetahui kondisi siswa sebelum diberikan intervensi Terapi SEFT.

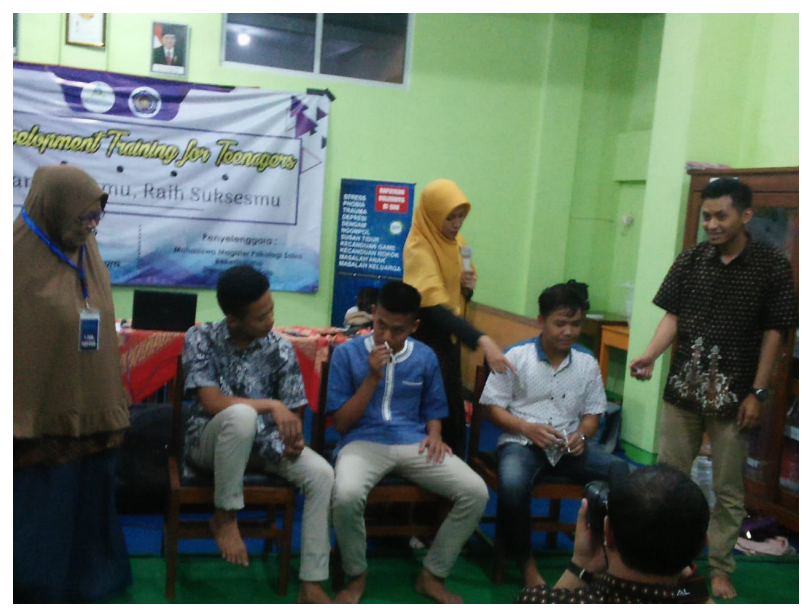

Gambar 1. Proses Asessmen

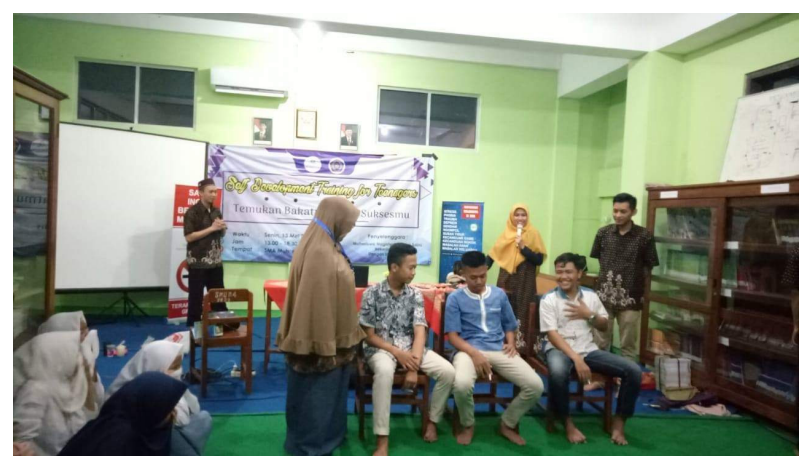

Gambar 2. Proses SEFT 
Setelah mengetahui tingkatan/skala keinginan merokok siswa, Kemudian siswa minum air putih diiringi dengan permohonan do'a sepenuh hati untuk dapat merasakan syukur. Siswa juga diwajibkan untuk melepaskan benda logam yang dipakai seperti perhiasan dan jam tangan. Demi kelancaran kegiatan, siswa juga diminta untuk mematikan handphone, dan menjauhkan diri dari alat-alat elektronik. Tujuannya adalah untuk menghindari energy toxin.

Setelah proses SEFT dilakukan, terjadi penurunan rasa nikmat dalam merokok, dan setelah SEFT dilakukan berulang sampailah pada jawaban sudah tidak mau lagi merokok. Para siswa sudah merasakan pusing, mual dan muntah saat mencium bau rokok yang menandakan adanya perubahan mindset terhadap rokok. Hasil dari proses terapi SEFT dijabarkan pada Tabel 1.

Merokok merupakan salah satu gangguan perilaku secara psikologis. Gangguan perilaku ini sudah tercatat dalam gangguan perilaku secara mendunia. Oleh karena itu intervensi perilaku merokok ini penting untuk dilakukan. Berdasarkan hasil di atas, sebelum diberikan Terapi SEFT, ketiga siswa laki-laki kelas 10 tersebut memiliki level yang cukup tinggi dalam merasakan kenikmatan rokok yaitu level 7-9 dengan intensitas merokok 4-8 batang perhari. Intensitas merokok dengan jumlah 4-8 batang perhari merupakan tergolong sedang. Sebagaimana Teori Aritonang (dalam Komasari \& Helmi, 2000) yang mengelompokan perilaku merokok berdasarkan intensitas (jumlah) rokok yang dihisap perhari, yaitu kategori rendah apabila merokok antara 1-4 batang per hari, kategori sedang apabila merokok 5-14 batang per hari dan kategori berat merokok lebih dari 15 batang perhari. Intensitas merokok responden yang tergolong sedang menjadi sebuah data yang mengkhawatirkan dikarenakan dapat mengarah pada golongan perokok yang berat. Seperti halnya pada hasil survei yang dilakukan oleh Badan Pusat Statistik pada tahun 2016 yaitu $34,71 \%$ anak usia 5-17 tahun diketahui menghisap lebih dari 70 batang rokok perminggu (Susenas, 2016).

Ketiga responden yang memasuki perilaku merokok kategori sedang ini diketahui berjenis kelamin laki-laki. Perokok dengan jenis kelamin laki-laki memang hingga saat ini masih menjadi perhatian khusus. Hal ini dikarenakan perilaku merokok sudah dianggap sebagai hal yang wajar bagi remaja khususnya kaum Adam (Isfandari \& Lolong, 2014). Penelitian lainnya juga mengungkapkan bahwa responden yang memiliki perilaku merokok berjenis kelamin laki-laki ditemukan sebanyak 100\% dibandingkan perempuan (Haryanto, 2016).

Tabel 1. Hasil Terapi SEFT pada siswa

\begin{tabular}{|c|c|c|c|c|c|}
\hline No & $\begin{array}{l}\text { Inisial } \\
\text { Siswa }\end{array}$ & $\begin{array}{l}\text { Penyebab } \\
\text { Merokok }\end{array}$ & $\begin{array}{l}\text { Tingkatan } \\
\text { Merokok } \\
\text { (Pre Terapi) }\end{array}$ & Gejala Pasca Terapi & $\begin{array}{c}\text { Tingkatan } \\
\text { Merokok } \\
\text { (Pasca Terapi) } \\
\end{array}$ \\
\hline 1. & $\mathrm{AA}$ & $\begin{array}{l}\text { Teman-teman } \\
\text { lingkungan } \\
\text { rumahnya sejak } \\
\text { SD }\end{array}$ & $\begin{array}{l}\text { Lv. } 7 \text { ( } 4-7 \text { batang } \\
\text { perhari) }\end{array}$ & $\begin{array}{l}\text { mulai merasakan pusing, } \\
\text { mual jika mencium bau } \\
\text { rokok bahkan menghisap } \\
\text { rokok }\end{array}$ & Lv. 2 \\
\hline 2. & $\mathrm{BD}$ & $\begin{array}{l}\text { Teman-teman } \\
\text { lingkungan } \\
\text { rumahnya sejak } \\
\text { lulus SD }\end{array}$ & $\begin{array}{l}\text { Lv. } 9 \text { ( } 5 \text { batang } \\
\text { perhari) }\end{array}$ & $\begin{array}{l}\text { mengalami mual, hampir } \\
\text { muntah dan mulai jijik } \\
\text { serta tidak suka dengan } \\
\text { rokok }\end{array}$ & Lv. 2 \\
\hline 3. & HR & $\begin{array}{l}\text { Teman-teman } \\
\text { nongkrong sejak } \\
\text { lulus SD }\end{array}$ & $\begin{array}{l}\text { Lv. } 9 \text { (5-8 batang } \\
\text { perhari) }\end{array}$ & $\begin{array}{l}\text { refleks mematikan putung } \\
\text { rokoknya serta diikuti mual } \\
\text { dan muntah, mulai tidak } \\
\text { mau merokok lagi karena } \\
\text { rasanya tidak enak dan } \\
\text { tidak nikmat sebelumnya }\end{array}$ & Lv. 3 \\
\hline
\end{tabular}


Bahkan prevalensi perokok laki-laki Indonesia di ASEAN merupakan yang tertinggi yaitu sebanyak 66\%. World Health Organization (WHO) tahun 2018 juga mengungkapkan jumlah perokok dunia saat ini telah mencapai 1,1 milyar orang yang diantaranya 17 juta remaja laki-laki yang merokok dan 7 juta remaja perempuan. Jumlah perokok remaja laki-laki Indonesia menjadi konsumen rokok terbesar di dunia setelah Negara China, Rusia, Amerika Serikat, dan Jepang (World Health Organization, 2018).

Jenis kelamin memengaruhi perilaku seseorang terutama anak laki-laki cenderung lebih suka bersosialisasi dengan teman sebaya terutama di luar sekolah. Hal tersebut didukung kebebasan dalam memperoleh informasi terkait merokok dibandingkan perempuan. Hal ini juga diperkuat dengan hasil penelitian Triastera (2009) bahwa ada perbedaan peran antara peran laki-laki dan perempuan dalam perilaku merokok. Laki-laki yang berperilaku merokok dapat memberikan kesan macho, berani dan pria sejati sedangkan perempuan lebih mendapatkan citra negatif di masyarakat yaitu nakal dan jauh dari kesan feminism.

Ketiga subjek yang merupakan siswa SMA laki-laki kelas 10 berusia diatas 15 tahun merupakan usia dalam proses perkembangan remaja yakni dalam masa periode peralihan dan perubahan yang mulai memiliki berbagai masalah dalam proses pencarian identitas diri serta berimajinasi, keingintahuan dan keinginan untuk mencoba yang kuat (Sarwono, 2015). Usia yang identik dengan coba-coba membuat remaja berperilaku merokok dan melakukan perilaku menyimpang lainnya (Fahrosi, 2013). Perilaku merokok yang dilakukan remaja ini seringkali tanpa memikirkan akibat yang didapatkan kedepannya.

Sebelum melakukan terapi SEFT, juga diberikan psikoedukasi atau pengetahuan mengenai bahayanya merokok yang dapat mengancamkesehatan fisikdan psikis. Pemberian pengetahuan ini dapat menjadi awalan dalam memberikan SEFT pada siswa. Haryanto (2016) memaparkan bahwa pengetahuan merupakan kepercayaan yang benar, apa yang diketahui atau hasil pekerjaan dalam mengetahui. Pekerjaan tahu tersebut adalah hasil dari pengenalan, kesadaran, insaf, mengerti, dan pandai.
Pengetahuan itu adalah semua yang ada dalam isi pikiran. Jadi pengetahuan merupakan hasil proses dari usaha manusia untuk mengetahui suatu hal. Dengan pengetahuan ini diharapkan remaja mampu mengekspresikan persepsi atau pendapatnya sesuai dengan pemahamannya mengenai rokok.

Menurut Notoatmodjo (2007) pengetahuan atau kognitif merupakan domain yang sangat penting untuk terbentuknya perilaku seseorang. Berdasarkan dari pengalaman dan penelitian yang dilakukan ternyata perilaku yang didasari oleh pengetahuan akan lebih menyerap/ memiliki makna dibandingkan perilaku yang tanpa didasari oleh pengetahuan. Perilaku baru seseorang berdasarkan pengetahuan yang telah ditimba dapat menjadi proses yang berurutan yaitu kesadaran, merasa tertarik, menimbangnimbang, trial, dan adaption. Kondisi remaja yang memiliki pengetahuan ini dapat menjadi pegangan dalam menjalankan proses SEFT. Sehingga nantinya perilaku yang baru akan lebih menyerap karena didasarkan pada pengetahuan.

SEFT adalah sebuah terapi dengan beberapa gerakan sederhana dan digabungkan dengan unsur spiritual berupa doa sehingga menyebutnya dengan amplifying effect (efek pelipat gandaan). Terdapat 3 tahap dalam terapi SEFT yaitu pertama The Set Up saat melakukan perlawanan psikologis, misalnya berupa keyakinan bawah sadar negatif dalam diri seseorang contohnya "saya tidak bisa lepas dari kecanduan rokok" pada set up kita melakukan doa dengan khusyu, ikhlas dan pasrah. Kedua The Tun In dalam keadaan tun in kita mengarahkan fikiran terhadap keluhan yang dirasakan dan ketiga adalah The Tapping dalam langkah ketiga dengan mengetuk ringan dengan ujung jari pada titik tertentu pada tubuh diseerai dengan tun in (Mustaqim \& Rahman, 2016).

SEFT sebagai terapi yang menyebabkan kondisi tubuh seseorang menjadi relaks, dimana relaksasi dapat menghasilkan efek fisiologis yang bertolak belakang dari efek akibat kecemasan seperti denyut jantung menurun, aliran darah meningkat dan stabilitas neuromuskular (Kaplan, Sadock, \& Grebb, 1997). Kondisi ini yang menyebabkan gelombang otak seseorang menjadi menurun, yang awalnya Beta menjadi Alpa. Sehingga kondisi ini memudahkan 
terapis untuk memasukkan sebuah informasi ke alam bawah sadar siswa untuk mengubah persepsi tentang rokok dan kebiasaan dalam merokok. Terapi SEFT juga memunculkan konsep spiritual dan do'a selama proses terapi. Hal ini memungkinkan seseorang lebih cepat menjadi relaks serta cepat menerima sugesti yang sifatnya mengajak untuk mengingatkan dan berdizikir hanya kepada Yang Maha Kuasa (Aminuddin, 2019).

Pemberian terapi Spiritual Emotional Freedom Technique atau disingkat SEFT ini sangat bermanfaat bagi siswa yang ingin menurunkan skala kebiasaan merokok yang tinggi menjadi menurun. Kondisi ini sesuai dengan hasil penelitian yang dilakukan oleh Sulifan \& Muhid (2014) yang menemukan hasil bahwasanya terapi SEFT efektif untuk mengurangi perilaku merokok pada siswa SMA Negeri 1 Taman Sidoarjo yakni subjek lebih banyak mengisap rokok sebelum diberikan terapi SEFT dibandingkan dengan setelah diberi terapi SEFT. Hal ini menunjukkan bahwa terapi SEFT terbukti efektif dalam menurunkan perilaku subjek Pre test dan Post test.

Hasil penelitian ini juga didukung oleh penelitian Sulifan \& Muhid (2014) didapatkan bahwa ada perbedaan perilaku merokok sebelum dan sesudah diberikan terapi SEFT. Responden lebih banyak mengisap rokok sebelum diberi terapi SEFT dibandingkan dengan setelah diberi terapi SEFT. Penelitian lain yang dilakukan oleh Yugistyowati dan Rahmawati (2018) juga menunjukan terdapat pengaruh signifikan pada terapi SEFT terhadap motivasi berhenti merokok pada remaja di Dusun Semampir Sedayu 2, Bantul, Yogyakarta. Selain itu intensitas merokok responden siswa SMA N 5 Kediri sebelum dilakukan terapi Spiritual Emosional Freedom Technique (SEFT) adalah sebagian besar perokok sedang sebanyak $(71,4 \%)$ dan setelah dilakukan terapi Spiritual Emosional Freedom Technique (SEFT) adalah setengahnya perokok ringan sebanyak $(50,0 \%)$ dengan hasil analisis menunjukkan bahwa terapi SEFT efektif terhadap intensitas merokok (Etika dan Wijaya, 2015). Dari hasil penelitian yang dilakukan beberapa terapis ini juga menjadi hasil yang memuaskan pada Terapi dapat menurunkan intensitas kebiasaan merokok masyarakat di kelurahan Sambutan kota Samarinda (Aminuddin dkk, 2019)

Uji coba pemberian terapi berhenti merokok dengan SEFT untuk para siswa SMA dirasakan sangat bermanfaat bagi siswa terutama generasi muda. Terapi SEFT merupakan sebuah terapi yang sangat praktis dilakukan selama ada niat dan kemauan dari responden. Pengurangan merokok dapat dilakukan dengan berulang kali untuk mendapatkan hasil yang relatif permanen. Semoga dengan terapi SEFT yang dilakukan bisa membuat siswa untuk berhenti merokok dan bisa mengganti aktivitasnya dengan aktivitas lain yang lebih bermanfaat kepada diri dan orang lain.

\section{SIMPULAN}

Kegiatan Pengabdian yang telah dilakukan oleh Tim Pengabdian Magister Psikologi UMS dapat disimpulkan bahwa terapi SEFT pada kasus siswa yang mengalami kecanduan merokok menunjukkan adanya penurunan skala kenikmatan yang dirasakan siswa. Bahkan terdapat siswa yang merasakan mual, pusing, pahit, batuk bahkan sampai muntah - muntah. Uji coba yang diberikan pada siswa perokok aktif di SMA Muh. PK Al-Kautsar memberikan hasil yang signifikan pada tahap terapi pertama kali, hasil dari pemberian terapi merokok ini dapat menurunkan level kenikmatan pada siswa yang semula pada level 7-9 berubah menjadi level 2-3.

Pemberian terapi SEFT ini dapat mengubah mindset siswa untuk menurunkan aktivitasnya berhenti merokok, dengan perasaan mual, muntah dan pusing saat mencium bau rokok dan merasakan hambar, tidak enak seperti semula saat mengkonsumsi rokok. Ketika keinginan atau motivasi ingin berhenti merokok dari siswa itu tidak ada maka kebiasaan merokoknya bisa kembali walaupun rasanya sudah tidak enak lagi, pahit atau hambar tapi mereka paksakan, apalagi kalau tidak mau keluar dari lingkungan yang mempengaruhi mereka untuk merokok.

\section{PERSANTUNAN}

Terima kasih penulis haturkan kepada Rektor Universitas Muhammadiyah Surakarta yang telah mendukung dengan dana untuk menebar ilmu Psikologi untuk kebermanfaatan 
di masyarakat. Selain itu ucap terima kasih juga penulis sampaikan kepada Kepala Sekolah SMA Muhammadiyah Al Kautsar Program Khusus Kartasura yang menerima kerjsama ini dengan hangat agar siswa SMA Muhammadiyah Al Kautsar Program Khusus Kartasura mampu menyelesaikan permasalahan yang akan mengganggu sebagian masa depannya.
Kepada siswa SMA Muhammadiyah Al Kautsar Program Khusus Kartasura, terima kasih atas semangatnya, tetap bertahan mengikuti tahap demi tahap kegiatan ini, sehingga perilaku merokok yang merupakan jembatan pembuka penyalahgunaan NAPZA bisa diputus dengan kegiatan ini.

\section{DAFTAR PUSTAKA}

Ali, M. (2010). Panduan Hidup Sehat. Kompas Media Nusantara : Jakarta.

Aminuddin, M., Samsugito, I., Nopriyanto, D., \& Puspasari, R. (2019). Terapi Seft Menurunkan Intensitas Kebiasaan Merokok Di Kelurahan Sambutan Kota Samarinda. JPPM (Jurnal Pengabdian dan Pemberdayaan Masyarakat), 3(2), 329-335.

Badan Pusat Statistik. (2016). Data Susenas 2016. Jakarta (ID): Badan Pusat Statistik Indonesia.

Depatermen Kesehatan Republik Indonesia. (2013). Riset Kesahatan Dasar 2013. Badan Penelitian dan Pengembangan Kesehatan Kementrian Kesehatan RI. http://www.depkes.go.id/resources/ download/general/Hasil\%20Riskesdas\%202013.pdf. Diakses tanggal 8 Desember 2019.

Etika, A. N., \& Wijaya, D. S. (2015). Pengaruh Terapi Spiritual Emotional Freedom Technique (SEFT) Terhadap Intensitas Merokok Pada Siswa. Care: Jurnal Ilmiah Ilmu Kesehatan, 3(3), 12-18.

Fahrosi, A. (2013). Perbedaan Tingkat Pengetahuan tentang Bahaya Merokok pada Remaja SMP di Pedesaan dan Perkotaan di Kabupaten Jember. Skripsi. Jember: Program Studi Ilmu Keperawatan Universitas Jember.

Haryanto T. (2016). Hubungan Persepsi Perokok Aktif Tentang Perokok Pasif dengan Motivasi Berhenti Merokok di Dusun Brajan Kasihan Bantul Yogyakarta. Skripsi. Yogyakarta: Universitas Alma Ata Yogyakarta.

Isfandari, S., \& Lolong, D. B. (2014). Analisa faktor risiko dan status kesehatan remaja Indonesia pada dekade mendatang. Buletin Penelitian Kesehatan, 42 (2 Jun), 122-130.

Kaplan, H., Sadock, B., \& Grebb, J. (1997). Sinopsis psikiatri. Jakarta: Binapura Aksara.

Kementerian Kesehatan Republik Indonesia. (2017). Riset kesehatan dasar tahun 2017. Jakarta: Kementerian Kesehatan Republik Indonesia.

Kementerian Perencanaan Pembangunan Nasional. (2014). Rencana Pembangunan Jangka Menengah Nasional (RPJMN) 2015-2019 Buku I. Badan Perencanaan Pembangunan Nasional,Jakarta. 311 hal.

Komasari, D., \& Helmi, A. F. (2000). Faktor-Faktor Perilaku Merokok Pada Remaja. Jurnal Psikologi Universitas Gadjah Mada, 2.

Lian, T. Y., \& Dorotheo, U. (2018). The Tobacco Control Atlas: ASEAN Region, Fourth Edition. Thailand: Southeast Asia Tobacco Control Alliance (SEATCA).

Mufaza, F. Y. (2015). Peran rokok terhadap kualitas hidup (evaluasi menggunakan kuesioner SF-36v2 antara perokok dan non perokok laki-laki) (Bachelor's thesis, UIN Syarif Hidayatullah Jakarta: Fakultas Kedokteran dan Ilmu Kesehatan, 2015).

Mustaqim, A., \& Rahman A. (2016). Ruqyah Asy-Syar'iyyah. Jakarta: Shahih.

Notoatmodjo, S. (2007). Ilmu Kesehatan Masyarakat. Jakarta: PT Renika Cipta. 
Nurjanah, D. S. (2019). Terapi Kecanduan Rokok dengan Menggunakan Metode Spiritual Emotional Freedom Technique (Seft). Syifa al-Qulub, 3(2), 112-119. DOI :10.15575/saq.v3i2.3536.

Sarwono, S. W. (2015). Psikologi Remaja. Jakarta: Rajawali Pers.

Saptutyningsih, E. (2015). Esai Tentang Produktivitas dan Keputusan Merokok (Doctoral dissertation, Universitas Gadjah Mada).

Sulifan, Y., \& Muhid, S. (2014). Efektifitas Terapi SEFT (Spiritual Emotional Freedom Technique) untuk Mengurangi Perilaku Merokok Remaja Madya. Jurnal Psikologi Tabularasa Volume, 9 (1), 86-95.

Triastera I. (2009). Fenomena Konsumen Rokok Era Baru: Perilaku Merokok Terhadap Citra Simbolisme Personal. Skripsi. Yogyakarta: Universitas Atma Jaya Yogyakarta.

World Health Organization. (2018). World no tobacco day : tobacco heart disease. Geneva: World Health Organization.

Yugistyowati, A., \& Rahmawati, R. (2018). Pengaruh Terapi Spiritual Emotional Freedom Technique (SEFT) Terhadap Motivasi Berhenti Merokok Pada Remaja. Jurnal Keperawatan Respati Yogyakarta, 5, 34-38.

Zainuddin, F, A. (2006). SEFT For Healing + Success + Happiness + Greatness. Jakarta: Afzan Publishing. 